\title{
Chimeric Antigen Receptor-Engineered T Cells for Immunotherapy of Cancer
}

\author{
Marc Cartellieri, ${ }^{1}$ Michael Bachmann, ${ }^{1,2}$ Anja Feldmann,, ${ }^{1}$ Claudia Bippes, ${ }^{1}$ Slava Stamova, ${ }^{1}$ \\ Rebekka Wehner, ${ }^{1}$ Achim Temme, ${ }^{2,3}$ and Marc Schmitz ${ }^{1,2}$ \\ ${ }^{1}$ Institute of Immunology, Medical Faculty, Technical University of Dresden, Fetscherstraße 74, 01307 Dresden, Germany \\ ${ }^{2}$ Center for Regenerative Therapies Dresden, Tatzberg 47-49, 01307 Dresden, Germany \\ ${ }^{3}$ Department of Neurosurgery, Section Experimental Neurosurgery/Tumor Immunology, University Hospital, \\ Technical University of Dresden, Fetscherstraße 74, 01307 Dresden, Germany \\ Correspondence should be addressed to Michael Bachmann, michael.bachmann@tu-dresden.de \\ Received 30 November 2009; Accepted 15 February 2010 \\ Academic Editor: Zhengguo Xiao
}

Copyright ( $\odot 2010$ Marc Cartellieri et al. This is an open access article distributed under the Creative Commons Attribution License, which permits unrestricted use, distribution, and reproduction in any medium, provided the original work is properly cited.

$\mathrm{CD}^{+}$and $\mathrm{CD}^{+} \mathrm{T}$ lymphocytes are powerful components of adaptive immunity, which essentially contribute to the elimination of tumors. Due to their cytotoxic capacity, T cells emerged as attractive candidates for specific immunotherapy of cancer. A promising approach is the genetic modification of $\mathrm{T}$ cells with chimeric antigen receptors (CARs). First generation CARs consist of a binding moiety specifically recognizing a tumor cell surface antigen and a lymphocyte activating signaling chain. The CAR-mediated recognition induces cytokine production and tumor-directed cytotoxicity of T cells. Second and third generation CARs include signal sequences from various costimulatory molecules resulting in enhanced T-cell persistence and sustained antitumor reaction. Clinical trials revealed that the adoptive transfer of $\mathrm{T}$ cells engineered with first generation CARs represents a feasible concept for the induction of clinical responses in some tumor patients. However, further improvement is required, which may be achieved by second or third generation CAR-engrafted T cells.

\section{Introduction}

T-cell-based immunotherapy of tumors has gained much impetus by the finding that $\mathrm{CD}^{+}$cytotoxic T cells (CTLs) display a high capability to recognize and destroy malignant cells, which present peptides derived from tumor-associated antigens (TAAs) in a complex with the major histocompatibility complex (MHC) class I molecules [1]. CD4 ${ }^{+} \mathrm{T}$ cells recognizing peptides in the context of MHC class II molecules also play an important role in antitumor immunity [2]. $\mathrm{CD}^{+} \mathrm{T}$ cells improve the capacity of dendritic cells (DCs) to induce CTLs by the interaction between CD40 on DCs and CD40 ligand on activated $\mathrm{CD} 4^{+} \mathrm{T}$ cells. Furthermore, $\mathrm{CD} 4^{+}$ $\mathrm{T}$ cells provide help for the maintenance and expansion of CTLs by secreting cytokines such as interleukin- (IL-) 2 , and in addition they can eradicate tumor cells directly. The presence of TAA-specific and tumor-reactive T cells in peripheral blood of tumor patients has given rise to the concept of adoptive cell therapy (ACT), a promising but also challenging approach for tumor treatment [3]. In the meantime, in vitro activation, expansion, and reinfusion of TAA-specific autologous $T$ cells have been successfully applied for the treatment of virus-associated infections as well as viral and nonviral malignancies [3-6]. In particular, the infusion of autologous tumor-infiltrating $\mathrm{T}$ cells after lymphodepletion emerged as an attractive treatment modality for patients with metastatic melanoma [7]. Despite these promising effects the clinical efficiency of ACT for tumor patients is still limited. In addition, the isolation and expansion of naturally occurring TAA-specific T-cell clones is technically difficult, labor-intensive, and time consuming. Therefore, further improvement of current strategies based on the adoptive transfer of tumor-reactive $\mathrm{T}$ cells is required.

A promising approach to generate large populations of polyclonal $\mathrm{T}$ cells with a defined specificity for TAAs in a relatively short time is the genetic modification of $\mathrm{T}$ cells 


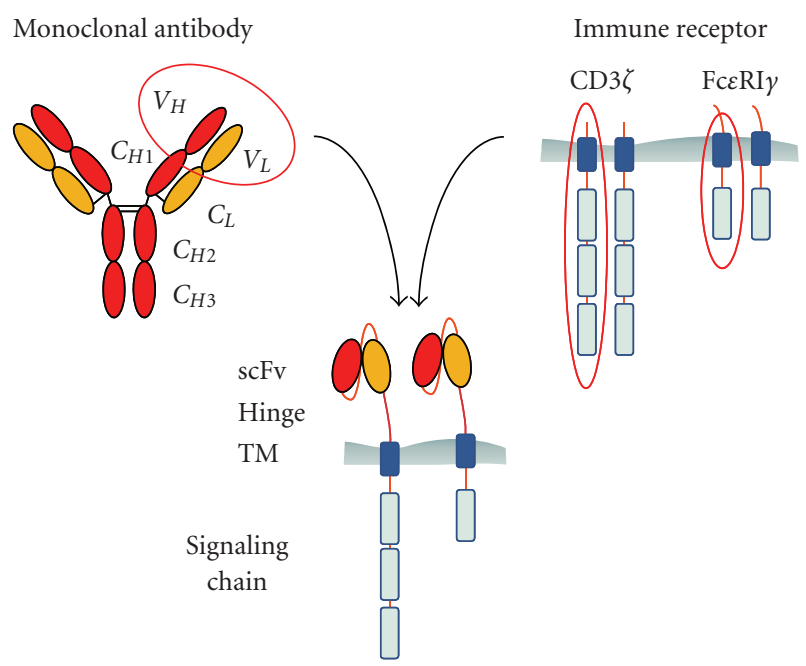

FIgURe 1: Principles of CAR architecture. CARs consist of a binding moiety, an extracellular hinge and spacer element, a transmembrane region (TM), and the signaling endodomain. Commonly the binding moiety consists of scFv derived from a TAA-specific monoclonal antibody and the signaling domain(s) come(s) from activating and costimulatory immune receptors.

using viral or nonviral transduction systems. One strategy uses natural T-cell receptor (TCR) $\alpha \beta$ heterodimers of known specificity and affinity for TAAs [8, 9]. However, it has been argued that formation of chimeric TCRs by pairing of endogenous and transgenic TCR chains may lead to de novo receptor specificities reacting against autologous MHC-peptide complexes and thereby mediate autoimmune reactions. Another general limitation of this approach is that each transgenic TCR is specific for a certain MHC-peptide complex and therefore is only suitable for MHC-matched tumor patients. Moreover, various immune evasion mechanisms of tumors such as the downregulation of different components of the MHC class I processing and presentation machinery might limit the success of this approach [10].

In an attempt to extend the recognition specificity of $\mathrm{T}$ lymphocytes beyond their classical MHC-peptide complexes, a gene-therapeutic strategy has been developed that allows redirecting $\mathrm{T}$ cells to defined tumor cell surface antigens. This strategy uses both the cellular and humoral arm of the immune response by assembling an antigen-binding moiety, most commonly a single chain variable fragment $(\mathrm{scFv})$ derived from a monoclonal antibody, together with an activating immune receptor (Figure 1). Once this artificial immune receptor is expressed at the surface of a modified $\mathrm{T}$ lymphocyte, upon binding of the $\mathrm{scFv}$ to its antigen an activating signal is transmitted into the lymphocyte, which in turn triggers its effector functions against the target cell (Figure 2). In the first attempts to reconfigure $\mathrm{T}$ cells with antibody specificity the variable parts of the TCR $\alpha$ and $\beta$ chains were replaced with scFv fragments derived from monoclonal antibodies. These hybrid T-cell receptors were functionally expressed and recognized the corresponding antigens in a non-MHC-restricted manner [11-13]. As a consequence of the finding, that $\mathrm{CD} 3 \zeta$ chain signaling on its own is sufficient for T-cell activation $[14,15]$, the first "true" chimeric single-chain receptors were created by fusing a scFv directly to the $\mathrm{CD} 3 \zeta$ chain [16]. At that time this concept was called the "T body approach" [17]. Nowadays these types of artificial lymphocyte signaling receptors are commonly referred to as chimeric immune receptors (CIRs) or chimeric antigen receptors (CARs). The use of CARs to redirect $\mathrm{T}$ cells specifically against TAA-expressing tumor cells has a number of theoretical advantages over classical T-cell-based immunotherapies. In contrast to the longlasting procedure of in vitro selection, characterization, and expansion of T-cell clones with native specificity for MHCtumor peptide complexes, genetic modification of polyclonal T-cell populations allows to generate TAA-specific T cells in one to two weeks [18]. Engraftment with CARs enables T cells to MHC-independent antigen recognition (Figure 2); thus major immune escape mechanisms of tumors such as downregulation of MHC molecules are efficiently bypassed [19]. Furthermore, proliferation and survival of modified $\mathrm{T}$ cells can be improved by the implementation of a multitude of signaling domains from different immune receptors in a single CAR (Figure 3 ). In addition, $\mathrm{T}$ cells can be rendered more resistant against the immunosuppressive milieu in tumor tissue (Figure 3 ). In addition to cancer immunotherapy, CAR-modified lymphocytes have been successfully applied for the treatment of virus infections $[20,21]$, and more recently, first experimental studies have been published using CARs engrafted on regulatory $\mathrm{T}$ cells (Tregs) for the treatment of autoimmune diseases [22-24]. First clinical studies using CAR-modified T cells have been reported and a number of clinical trials are on the way. At this translational point towards a clinical application of CAR-modified $\mathrm{T}$ cells, this review summarizes various experimental approaches towards an improvement of CARs and discusses the prospects and future challenges using this immunotherapeutic strategy for cancer treatment.

\section{Design of Chimeric Antigen Receptors}

The general design of a CAR consists of a binding moiety, an extracellular hinge and spacer element, a transmembrane region, and the signaling endodomain (Figure 1). Commonly, the binding moiety consists of a scFv, comprising the light $\left(V_{L}\right)$ and heavy $\left(V_{H}\right)$ variable fragments of a TAAspecific monoclonal antibody joined by a flexible linker. Using such scFvs, $\mathrm{T}$ cells have been successfully redirected against TAAs expressed at the surface of tumor cells from various malignancies including lymphomas and solid organ tumors. An extensive overview of TAAs used as targets for CAR-modified $\mathrm{T}$ cells has been recently published by Sadelain and colleagues [25]. A major advantage of endowing $\mathrm{T}$ cells with non-MHC-restricted, antibody-derived specificity is that the potential target structures are no longer restricted to protein-derived peptides, but rather comprise every surface molecule on tumor cells including proteins with varying glycosylation patterns and nonprotein structures like gangliosides or carbohydrate antigens [26-29]. Thus, the panel of potential tumor-specific targets is enlarged. 


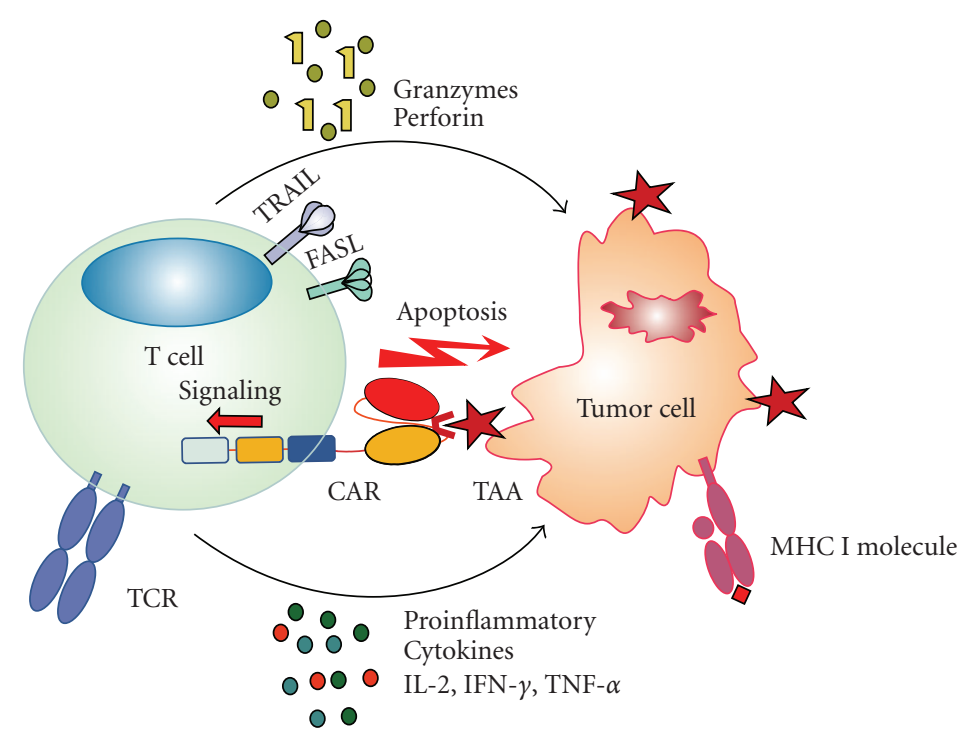

FIgURE 2: Antitumor effects mediated by CAR-engrafted T cells. CAR-modified T cells can recognize tumor cells via binding of the CAR to its TAA independent of TCR-MHC/Peptide interactions. As a result T cells are activated and can efficiently eliminate tumor cells by the secretion of perforin and granzymes as well as the expression of FasL and tumor necrosis factor-related apoptosis inducing ligand (TRAIL). In addition, other tumor-infiltrating immune cells can be activated by the secretion of various cytokines.

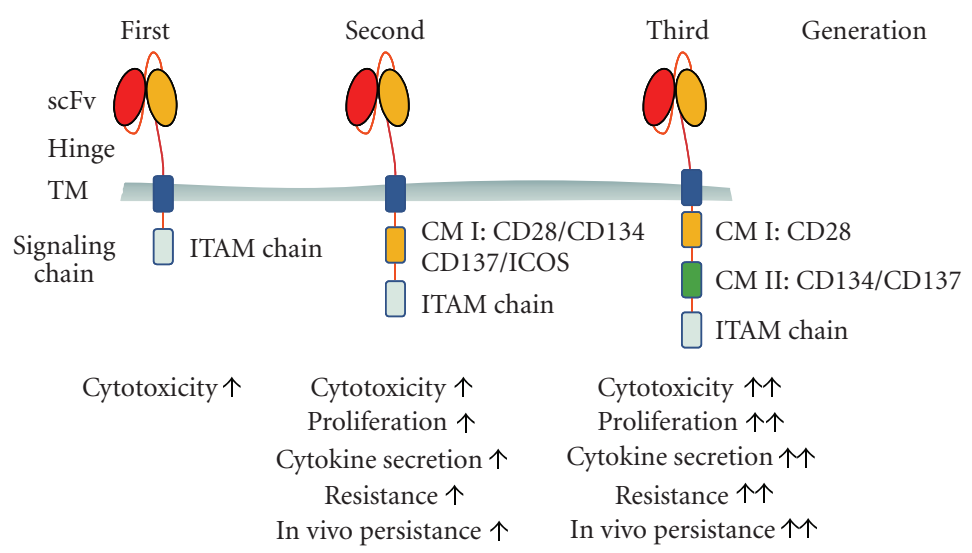

FIGURE 3: Evolution of CAR signaling capacities. First generation CARs transmitted activating signals only via ITAM-bearing signaling chains like $\mathrm{CD} 3 \zeta$ or $\mathrm{FcERI} \gamma$, licensing the engrafted T cells to eliminate tumor cells. Second generation CARs contain an additional costimulatory domain (CM I), predominantly the CD28 domain. Signaling through these costimulatory domain leads to enhanced proliferation, cytokine secretion, and renders engrafted T cells resistant to immunosuppression and induction of AICD. Recent developments fused the intracellular part of a second costimulatory molecule (CM II) in addition to CD28 and ITAM-bearing signaling chains, thus generating tripartite signaling CARs. $\mathrm{T}$ cells engrafted with third generation CARs seem to have superior qualities regarding effector functions and in vivo persistence.

Other binding moieties than scFvs have also been introduced into CARs and successfully used for predefined targeting of lymphocytes. For example, chimeric receptors incorporating receptor ligands like a vascular endothelial growth factor polypeptide, an integrin-binding peptide, heregulin, or an IL-13 mutein have been explored and tumor regression was demonstrated in mouse models [30-34]. Another group has successfully retargeted murine and human lymphocytes against hematopoetic tumors using a chimeric NKG2D receptor fused to the $\mathrm{CD} 3 \zeta$ chain [35-37]. The human NKG2D receptor recognizes several stress proteins like MHC class I chain-related (MIC) A/B and UL16 binding proteins (ULBP) upregulated in a number of tumor cells [38, 39]. Therefore, such an approach can be applied for a wide range of malignancies. One disadvantage of the classical CAR strategy using scFvs or other binding moieties is the limitation of appropriate surface antigens on tumor cells. One alternative possibility is the isolation of MHC-tumor peptide-specific antibodies from phage display libraries and their subsequent in vitro evolution resulting finally in high affinity scFvs, which then can be engrafted on $\mathrm{T}$ cells as part of a CAR [40]. 
Cellular activation through chimeric receptors differs from signaling triggered by natural TCRs in the way that binding affinities of the commonly used IgG-derived scFvs are several magnitudes higher than TCR affinities for MHCpeptide complexes $[41,42]$. So far, no general a priori rules can be defined for the functionality of any given binding moiety used in the context of a CAR. The magnitude of the cellular response of CAR-redirected $\mathrm{T}$ cells against antigen-expressing cells depends on a number of mutual interacting factors like the binding affinity of the $\mathrm{scFv}$ itself $[43,44]$, the effectiveness of surface expression of the CAR on the effector cell as well as antigen density, and accessibility of the epitope on the target cell [44-47]. An analysis of several scFvs with varying affinity for the same epitopes as parts of an otherwise similar CAR has shown that immunoreceptors with binding affinities below a $K_{d}$ of $\sim 10^{-8}$ activate engrafted $\mathrm{T}$ cells with similar efficiency irrespectively of antigen density on target cells [43]. Another study, however, stated that under suboptimal expression levels of both CAR and antigen, a high-affinity $\operatorname{scFv}\left(K_{d}<\right.$ $\left.10^{-8}\right)$ is less efficient than a low-affinity scFv $\left(K_{d} \sim 10^{-6}\right)$ in redirecting CAR-engrafted lymphocytes against tumor cells [44]. In a simplified way, one could argue that the affinity of the binding moiety must be high enough to establish an immunological synapse, which engages a certain number of activating immune receptors breaking the signal threshold for the initiation of cytotoxic effector functions. However, if binding of the effector cell to its target is too strong, the effector cell might strongly adhere to the target cell and is therefore unable to engage subsequently other target cells, thus limiting the overall antitarget effect [48]. A relative overexpression of a CAR in combination with high antigen density can even induce T-cell apoptosis rather than T-cell activation [46], although this might only hold true for CARs without costimulatory capacities. Besides the binding of the CAR itself to its antigen, the interaction of adhesion and accessory molecules at the surface of effector and target cells contributes to the formation of an immunological synapse and influences the overall antitarget effect [49]. One important consequence of these analyses is that CARs endowed with scFvs having reasonably low affinities should be able to discriminate between cells with low and high antigen expression at the surface and therefore enable the targeting of antigens, which are not tumor-specific, but rather overexpressed by malignant cells $[43,46,50]$. Some TAAs are shed from tumors and found in soluble form in patients sera. Importantly, CAR-mediated T-cell response is not inhibited by the presence of soluble antigens, which would be otherwise a major limitation for the clinical application [50, 51].

Most CARs comprise a hinge region between the binding and the transmembrane domain. The rationale for including a spacer region is to provide more flexibility and accessibility for the binding moiety, which might be otherwise buried by the dense glycocalyx shell covering $\mathrm{T}$ cells [52]. Examples of extracellular spacer regions include immunoglobulin domains like the fragment crystallizable $(\mathrm{Fc})$ regions of antibodies $[49,53-55]$ or immunoglobulin-like domains derived from the extracellular portions of $\mathrm{CD} 8 \alpha, \mathrm{CD} 28$,
TCR $\beta$ chain, or NKG2D [30, 35-37, 56-58]. Varying spacer regions within otherwise similar CARs can result in significant differences in cytokine secretion and killing efficiency of the modified $\mathrm{T}$ cells [59]. The requirement for a spacer region for efficient antigen recognition by CARengrafted lymphocytes seems to depend on the epitope position in the relevant antigen. Membrane-distal epitopes can be well engaged by CARs without extracellular spacer elements, whereas CARs equipped with scFvs recognizing a membrane-proximal epitope need a protruding hinge region for efficient activation of the engrafted lymphocytes [60, 61]. The transmembrane region of CARs is in most cases derived from homo- or heterodimeric type I membrane proteins like CD4, CD8, CD28, CD3 $\zeta$, or FceRI $\gamma$ [16, $49,54,56-58,62]$. A remarkable exception is a chimeric immunreceptor incorporating the full murine, respectively, human NKG2D receptor fused to the corresponding $\mathrm{CD} 3 \zeta$ chain. As NKG2D is a type II membrane protein, the signaling domain of $\mathrm{CD} 3 \zeta$ had to be fused to the N-terminus of the chimeric receptor. Once the adaptor protein DAP10 was coexpressed in the engrafted cells, the recombinant receptor was expressed at the surface in a sufficient way [3537].

Extraordinary attention has been paid to the intracellular signaling domains of chimeric receptors. The first generation of CARs only contains a single signaling unit, in most cases derived from the $\mathrm{CD} 3 \zeta$ chain or the FceRI $\gamma[17$, 63]. Several studies addressed the question, whether the TCR $\zeta$ chain, containing three immunoreceptor tyrosinebased activation motifs (ITAMs), performs better than the FceRI $\gamma(-\mathrm{Fc} \gamma)$ chain with a single ITAM in context of a CAR. Some studies reported that recombinant $\gamma$ - and $\zeta$ chain immunoreceptors activate grafted peripheral blood $\mathrm{T}$ cells with similar efficiency $[17,64]$. However, an in vivo study demonstrated the superior tumor eradication efficiency of $\mathrm{T}$ cells equipped with a $\mathrm{CD} 3 \zeta$-receptor compared to a Fc $\gamma$-receptor [65]. An explanation for this discrepancy might be the different time frame of analysis in these studies. Although $\mathrm{Fc} \gamma$-receptors have initially a higher surface expression than $\mathrm{CD} 3 \zeta$-receptors and activate primary human $\mathrm{T}$ cells in a comparable manner, over time the activation potential of the $\mathrm{Fc} y$ receptor seems to be more rapidly lost than $\mathrm{CD} 3 \zeta$-receptors [66]. The same author, however, observed that surface expression of $\mathrm{CD} 3 \zeta$ receptors is impaired by the intracellular portion of the $\mathrm{CD} 3 \zeta$ chain [66], a finding which is supported by the results of a recent study [67]. Nevertheless, over the past decade, CARs with single signaling units against a wide variety of TAAs have been successfully engrafted on native murine and human $\mathrm{T}$ cells including $\mathrm{T}$ cells from tumor patients $[62,68]$ and proved their antitumor efficiency both in vitro and in vivo $[10,25]$. Using immunocompromised mice strains challenged with xenografts either subcutaneously or orthotopically implanted, significant reduction in tumor growth or eradication could be shown for various tumor entities like B-cell lymphoma [69-71], colon carcinoma [72, 73], erb2-positive carcinomas [74], ovarian cancer [75, 76], prostate cancer [77-79], medulloblastoma $[32,80]$, and glioma [33]. 


\section{Improving Signaling Capacities - Second and Third Generation CARs}

Although first generation CARs could initiate a cytotoxic antitumor response in grafted $\mathrm{T}$ cells, it soon became obvious that signals from ITAM-bearing receptors alone can only induce transient cell division and suboptimal cytokine secretion $[81,82]$ but cannot provide prolonged polyclonal expansion and sustained antitumor reaction in vivo. According to the prevailing two-signaling model for lymphocyte activation, full activation and proliferation of $\mathrm{T}$ cells require a costimulatory signal through CD28-B7 interaction in addition to signaling through the TCR/CD3 complex [83]. Providing the costimulatory signal in trans through B7-expressing cells sustained proliferation of single ITAM-bearing CAR-expressing lymphocytes and lead to enhanced antitumor response in mouse models $[68,84]$. A more straight forward strategy comprised the CD28 signaling in the CAR concept, either in two separate molecules [85] or combined in a single CD28-ITAM receptor fusion protein $[53,86]$. Placement of the CD28 domain proximal to the $\mathrm{CD} 3 \zeta$ chain and immediately distal to the transmembrane domain resulted in good surface expression, whereas in the opposite way the surface expression seems to be inhibited [87]. Therefore, all published second generation CARs follow the general outline TM domain-CD28-ITAM-bearing signaling chain (Figure 3). Subsequently, it has been shown that the synergistic action of the two signaling domains in one single CAR resulted in sustained proliferation of grafted lymphocytes [88, 89], increased levels of IL-2 [90, 91], interferon (IFN) $-\gamma[73,90,91]$, and granulocyte macrophage colony-stimulating factor (GM-CSF) secretion [73] independent of exogenous B7/CD28 costimulation. Due to CD28 costimulation the expression of antiapoptotic proteins like $\mathrm{B}$-cell lymphoma- (Bcl-) 2 is upregulated and induction of activation induced cell death (AICD) is delayed [92, 93]. Studies in mouse models finally supported the in vitro findings that $\mathrm{T}$ cells grafted with recombinant CD28-ITAM receptors have also higher proliferation capacities resulting in an enhanced antitumor activity [73, 93-96]. A transgenic mouse model proved that even naïve resting $\mathrm{T}$ cells can become fully activated, proliferate in antigen-induced manner, and secrete IL-2 through a chimeric receptor incorporating the costimulatory $\mathrm{CD} 28$ sequences in addition to an activating ITAM receptor chain [97]. One major drawback off cellular immunotherapy might be that adoptively transferred cells are rapidly impaired in their effector function by the immunosuppressive milieu, which tumor cells create in their surroundings [98]. However, engrafting $\mathrm{T}$ cells with second generation CARs increases substantially the threshold of the modified cells against inhibitory effects mediated by transforming growth factor- $\beta[99,100]$ and against the suppressive action of Tregs [100]. Resistance to these cells is an important issue for immunotherapy, as tumor-infiltrating Tregs counteract against adoptively transferred tumor-specific T cells [101]. Another way of improving signaling capacities is the incorporation of Src family kinases or their adaptor molecules, which regulate the very beginning of the signaling cascade resulting from TCR triggering. The $56 \mathrm{kDa}$ Lck kinase is one of the Src-homology kinases, which most likely phosphorylates CD3 ITAM motifs after TCR engagement, and is noncovalently linked to either the CD4 or CD8 molecule. Incorporation of the p56Lck or its adaptor $\mathrm{CD} 4$ in a $\mathrm{CAR}$ with $\mathrm{CD} 3 \zeta$ or $\mathrm{CD} 28-\mathrm{CD} 3 \zeta$ signaling chains decreased signaling threshold of receptor grafted $\mathrm{T}$ cells [87].

In recent years, further costimulatory molecules from the B7 family and the tumor necrosis factor receptor superfamily came into the focus of research $[102,103]$. Not surprisingly, a number of these molecules were also tested in the context of CARs, leading to the development of the third generation of CARs with three different signaling moieties in the intracellular chain (Figure 3). Brentjens et al. generated a series of chimeric receptors bearing signaling sequences from CD28, DAP10, CD134 (OX40), and CD137 (4-1BB) in addition to the $\mathrm{CD} 3 \zeta$ chain [96]. However, only the $\mathrm{CD} 28-\mathrm{CD} 3 \zeta$ chain construct was able to induce significant proliferation of grafted $\mathrm{T}$ cells after antigen contact independently of exogenous B7 costimulation. In contrast, when cells expressing B7 molecules were used as targets, all $\mathrm{T}$ cells grafted with CARs having $\mathrm{CD} 3 \zeta$ and costimulatory sequences proliferate better than those cells grafted with $\mathrm{CD} 3 \zeta$ CAR [96]. Also in terms of IL2 and IFN- $\gamma$ secretion $\mathrm{T}$ cells grafted with $\mathrm{CD} 28-\mathrm{CD} 3 \zeta$ CAR always out-competed $\mathrm{T}$ cells modified with receptors having other signaling combinations [96]. Similar results were obtained by another study, which also included the inducible costimulator (ICOS) in the analyzed series of signaling moieties [92]. Secretion of inflammatory cytokines like tumor necrosis factor- (TNF-) $\alpha$, IFN- $\gamma$, and GM-CSF was similar for $\mathrm{T}$ cells engrafted with $\mathrm{CD} 28-\mathrm{CD} 3 \zeta$ and ICOS-CD $3 \zeta$ CARs; however, IL-2 secretion and induction of proliferation was better with the $\mathrm{CD} 28-\mathrm{CD} 3 \zeta$ construct [92]. Thus, both studies have proven that for antigen-induced proliferation and high-level cytokine secretion the signal from CD28 is required and sufficient, but inclusion of further costimulatory molecules enhances proliferation capacities and apoptosis resistance in the grafted T cells [104]. It is now established that physiologically optimal activation requires CD28 engagement followed by costimulation through other T-cell signaling molecules [105]. Consequently, CARs which can simultaneously transmit multitude signals from CD28, $\mathrm{CD} 3 \zeta$, and an additional costimulatory molecule in the engrafted cell have been constructed. One of the most important "secondary" costimulatory molecules is OX40 (CD134), for which studies have shown that its signaling can further augment CD28-activated T-cell responses, enhancing proliferation, cytokine secretion, and survival [106]. Integration of OX40 in a third generation CAR in combination with $\mathrm{CD} 28$ and $\mathrm{CD} 3 \zeta$ chain leads to sustained in vitro proliferation and increased IL-2 secretion by grafted human primary $\mathrm{T}$ cells [28]. A number of studies pointed out the important role of the CD137/CD137L interaction for Tcell survival and AICD resistance [107-109]. Integration of CD137 signaling in CARs increased expression of antiapoptotic protein $\mathrm{Bcl}-\mathrm{xL}$, induced sustained proliferation and survival of the grafted $\mathrm{T}$ cells, and was associated with higher effector cytokine production and antigen-specific 
tumor cell lysis $[67,110,111]$. In a mouse model, an established xenograft was controlled by retargeted $\mathrm{T}$ cells containing a CD28-CD137-CD3 $\zeta$ CAR [112]. If targeted cancer cells are B7.1/B7.2 positive, chimeric CD137-CD3 $\zeta$ CARs can be even more sufficient than a CD28-CD3 $\zeta$ CAR [110]. Despite these encouraging results, the use of CARs with a tripartite signaling domain might also have its pitfalls. It has to be carefully investigated, if CARs with tripartite signaling moieties reduce the signal threshold to a level, where activation of grafted $\mathrm{T}$ cells can occur without antigen triggering. Signal leakage might turn out to be a problem for clinical applications of third generation CARs.

\section{Striving for Optimal Function of Adoptively Transferred CAR-Modified Cells}

Research in ACT for cancer focused on $\mathrm{CD}^{+}$effector cells for a long time, because this population mediates mainly the cytotoxic effector functions [3, 113]. Meanwhile, the important function of $\mathrm{CD}^{+} \mathrm{T}$ helper cells for mounting an efficient antitumor response has been demonstrated [114]. $\mathrm{CD}^{+} \mathrm{T}$ cells can be redirected in an MHC class II-independent manner towards TAAs similar to $\mathrm{CD}^{+} \mathrm{T}$ cells by engraftment with chimeric antigen receptors and even converted to efficient cytolytic effector cells [115117]. The cytotoxic response is essentially mediated via the perforin/granzyme pathway [116, Figure 2]. The cytokine profile after antigen-stimulation of CAR-engrafted $\mathrm{CD} 4^{+} \mathrm{T}$ cells is more diverse compared to their $\mathrm{CD}^{+}$counterparts by means of higher amounts of IL- 2 and TNF- $\alpha$ and exclusive IL-4, IL-6, and IL-10 secretion [110, 112]. In a transgenic mouse model it has been shown that adoptive transfer of CAR-grafted $\mathrm{CD}^{+}$and $\mathrm{CD}^{+} \mathrm{T}$ cells can reject tumor burdens much more efficient than adoptive transfer of grafted $\mathrm{CD}^{+} \mathrm{T}$ cells only [118]. Beside T cells expressing an $\alpha / \beta$ TCR, a small subpopulation of less than $5 \%$ of human blood T cells expresses an invariant $\gamma / \delta$ TCR. Subsets of human $\gamma / \delta$ T cells recognize stress ligands also expressed by tumor cells and therefore this T-cell population is another attractive candidate for cellular immunotherapy [119]. $\gamma / \delta$ $\mathrm{T}$ cells can be selectively expanded by administration of aminobisphosphonates in vitro and genetically modified with CARs using retroviral vector systems. CAR-grafted $\gamma / \delta$ T cells secrete IL- 2 and IFN- $\gamma$ upon antigen stimulation and are able to selectively kill TAA-expressing tumor cells [120]. In conclusion, not only $\mathrm{CD}^{+}$effector cells should be taken into account when deciding clinical application of adoptive transfer of CAR-engineered T cells.

An important issue for the transfer of ACT to the clinic is the in vitro cultivation and expansion of the CAR-modified cells to ensure sufficient cell numbers for the treatment [18]. Our current understanding of the development of naïve $\mathrm{CD}^{+}$and $\mathrm{CD}^{+} \mathrm{T}$ cells after antigen-activation proposes the generation of two main subsets of cells termed effector memory $\left(\mathrm{T}_{\mathrm{EM}}\right)$ and central memory $\mathrm{T}$ cells $\left(\mathrm{T}_{\mathrm{CM}}\right)$. The development and differentiation of these two populations is under intense investigation $[121,122]$. Studies with various mouse models have shown that these two T-cell subsets are unequally suited for a successful adoptive transfer. $\mathrm{T}_{\mathrm{EM}}$ have enhanced cytotoxic effector function, but are sensitive to AICD and persist only for short time in the host after adoptive transfer, whereas administration of $\mathrm{T}_{\mathrm{CM}}$ results in long-term memory response and efficient tumor rejection $[123,124]$. In nonhuman primates, adoptive transfer of a virus-specific $\mathrm{CD}^{+} \mathrm{T}$-cell clone derived from $\mathrm{CD}^{+}{ }^{+} \mathrm{T}_{\mathrm{CM}}$ but not from CD62- $\mathrm{T}_{\mathrm{EM}}$ can also establish persistent $\mathrm{T}$ cell memory [125]. Thus, optimized culture conditions have to be established, which preserve the functional phenotype of $\mathrm{T}_{\mathrm{CM}}$ for CAR-engrafted $\mathrm{T}$ cells before adoptive transfer. For long-term culture and expansion of $\mathrm{T}$ cells routinely high doses of IL-2 were used, leading to the development of late effector cells less qualified for long-lasting antitumor responses after adoptive transfer [126]. Recently, other members of the IL-2 related cytokine family like IL-7, IL15 , and IL-21 have raised considerable interest for their potent effect on activation and expansion of T cells [127129]. T cells grafted with a first generation CAR could be rapidly expanded in the presence of IL-15 and could better control tumor growth after transfer in a tumor-bearing immunocompromised mouse strain [69]. Transgenic expression of a homeostatic cytokine like IL-7 or IL-15 or their high-affinity receptors in addition to a CAR in genetically modified cells may be an option to ensure sufficient supply with these cytokines in vivo $[130,131]$. Another way to improve in vitro expansion and in vivo persistence after adoptive transfer is the engraftment of CARs in antigenspecific $T$ cells reactive against common viral infections like Epstein-Barr virus (EBV) or cytomegalovirus (CMV). EBVspecific T cells have been engrafted with CARs against B-cell malignancies, and rapid expansion of genetically modified cells could be driven by EBV-transformed B-lymphoblastoid cell lines [132-134]. CAR-modified EBV-specific T cells generated from healthy donors or tumor patients showed antitumor effects in xenograft mouse models $[135,136]$.

The condition of ex vivo generated CAR-modified $\mathrm{T}$ cells is also highly influenced by the method chosen for the genetic modification. In general, retro- or lentiviral gene transfer is widely used for this purpose. For retroviral gene transfer, activation of $\mathrm{T}$ lymphocytes by TCR triggering is a prerequisite, and also in case of lentiviral vectors the transduction efficiency is highly increased in this way. However, it has been argued that TCR activation impairs the half-life, repertoire, and immune competence of the transduced cells [137]. Furthermore, a study in a mouse model revealed that effector cells derived from naïve $\mathrm{T}$ cells rather than from memory $\mathrm{T}$ cell subsets might be better suited for ACT [138]. Therefore, preactivation via TCR for transduction might reduce fitness of engineered $\mathrm{T}$ cells for adoptive transfer. In principal, $\mathrm{T}$ lymphocytes can be transduced using lentiviral vectors without preactivation preconditioning the $\mathrm{T}$ cells with stimulating cytokines like IL-2, IL-7, or IL-15 [139]. Alternatively, different nonviral gene transfer methods have been evaluated for genetic modification of $\mathrm{T}$ cells with CARs. These methods might be more cost efficient and safety issues regarding the use of viral vectors can be circumvented. Electroporation with naked DNA has been successfully used for the modification 
of naïve cord-blood cells with a CAR construct; however, a constant selective pressure is necessary during the in vitro prolongation of the modified cells to avoid transgene loss [140]. In addition, transfection efficiency of nonviral gene transfer is clearly less efficient compared to transduction and the ex vivo manufacturing time is considerably prolonged to generate sufficient numbers of modified cells. During this time cells might differentiate in exhausted late effector cells less suited for immunotherapy. Recently, $\mathrm{T}$ cells have been electroporated with CAR encoding mRNA; however, the surface expression of CARs was transient and rapidly decreasing after a few days [141]. Other studies use different retrotransposon systems for the genetic modification of primary human $\mathrm{T}$ cells or umbilical cord blood $\mathrm{T}$ cells with CARs and could demonstrate safe integration and long-term expression of the transgene. However, initial transfection efficiency was still very low and CAR-positive $\mathrm{T}$ cells had to be expanded over several weeks to generate sufficient numbers [142-144]. At the present stage, viral gene transfer seems to be the most feasible way to ensure stable long-time expression of CARs in grafted cells; however, if methods of nonviral gene modification are improving in terms of gene transfer rates and stability of expression, they might become a safer and cheaper alternative for clinical applications.

\section{Clinical Studies Based on CAR-Modified T Cells}

Clinical studies based on the antitumor effects of CARengineered $\mathrm{T}$ cells in vitro and in various animal models have been conducted to evaluate the potential of $\mathrm{T}$ cells modified with first generation CARs for the treatment of patients. Such a clinical study was performed to evaluate the efficiency of $\mathrm{T}$ cells modified with a CAR displaying CD4 as binding moiety for the human immunodeficiency virus (HIV) envelope fused to intracellular $\mathrm{CD} 3 \zeta$ signaling chain in HIV-infected patients [21]. Twenty-four HIV-positive patients received a single infusion of $2-3 \times 10^{10}$ autologous genetically modified $\mathrm{CD}^{+}$and $\mathrm{CD}^{+}{ }^{+} \mathrm{T}$ cells administered with or without IL2. Treatment was well tolerated and a persistence of the CAR-engineered T cells was observed. Modified T cells were detected in $1-3 \%$ of blood mononuclear cells at 8 weeks and $0.1 \%$ at 1 year after infusion. No significant mean change in plasma HIV RNA or blood proviral DNA was found.

More recently, first clinical trials were conducted to investigate the potential of CAR-modified $\mathrm{T}$ cells in tumor patients. In one study, three patients with metastatic renal cell carcinoma (RCC) were treated with $\mathrm{T}$ cells modified with a CAR recognizing carbonic anhydrase IX, which represents an antigen overexpressed on clear cell RCC $[145,146]$. IL2 was also administered subcutaneously. Infusions of the CAR-modified $\mathrm{T}$ cells were initially well tolerated. However, patients developed severe liver toxicities after four to five infusions, which was probably due to a destruction of carbonic anhydrase IX-expressing bile duct epithelial cells by the CAR-modified $\mathrm{T}$ cells. No clinical responses were observed.
In another clinical study, 14 patients with metastatic ovarian cancer were treated with T cells grafted with an $\alpha$ folate receptor-specific CAR [147]. Gene-modified T cells could be detected in the circulation in large numbers for the first two days after transfer, but then T-cell numbers rapidly declined to be barely detectable one month later in most patients. No clinical responses were found.

Whereas in the three clinical studies mentioned above $\mathrm{T}$ cells were genetically engineered using retroviral vectors, Park et al. reported on the adoptive transfer of $\mathrm{T}$ cells electroporated with a plasmid encoding for a L1-cell adhesion molecule-specific to neuroblastoma patients [148]. The persistence of CAR-modified T cells in the circulation was short in patients with bulky disease, but significantly longer in one patient with limited tumor burden. One of six treated patients showed a partial response.

Till et al. conducted a clinical trial in which patients with B-cell lymphoma or mantle cell lymphoma were treated with $\mathrm{T}$ cells modified by electroporation with a plasmid encoding a CD20-specific CAR [149]. Of seven patients, two maintained a previous complete response, one displayed a partial response, and four had stable disease.

In another clinical study, eleven neuroblastoma patients were treated with EBV-specific T cells engineered with a CAR recognizing the diasialoganglioside GD2 representing an antigen expressed by neuroblastoma cells [150]. Treatment was well tolerated. Four of eight patients with evaluable tumors had evidence of tumor necrosis or regression, including a sustained complete remission.

\section{Conclusions}

$\mathrm{T}$ cells play a major role in antitumor immunity. CD $8^{+} \mathrm{CTLs}$ efficiently destroy tumor cells, whereas $\mathrm{CD} 4^{+} \mathrm{T}$ cells improve the antigen-presenting capacity of DCs and support the stimulation of tumor-reactive CTLs. Following these findings T-cell-based immunotherapeutic strategies for the treatment of tumor patients were developed. A promising approach is the genetic modification of polyclonal $\mathrm{CD}^{+}$and $\mathrm{CD} 8^{+} \mathrm{T}$ cells with CARs. First generation CARs consist of a binding moiety specifically recognizing a tumor cell surface antigen and a lymphocyte activating signaling chain. $T$ cells modified with such CARs are capable of lysing tumor cells in vitro, and the adoptive transfer of engineered $\mathrm{T}$ cells results in tumor regressions in various mouse models. Recent clinical studies which are based on the administration of CARmodified $\mathrm{T}$ cells to tumor patients revealed that this strategy is feasible and safe. Despite these promising effects, a number of obstacles have still to be overcome for a successful tumor treatment with CAR-modified $\mathrm{T}$ cells. The immunogenicity of CARs can restrict the duration of treatment and thus can limit the overall antitumor effect. The development of CARspecific antibodies, however, can be potentially avoided by the use of humanized or human scFvs. Additional concerns are related to unexpected off-target toxicities mediated by CAR-engrafted T cells. Autoreactivity can be either induced by CAR-engrafted $\mathrm{T}$ cells recognizing normal tissues expressing the target antigen or CAR-mediated activation of native 
autoreactive $\mathrm{T}$ cells. Another obstacle for immunotherapeutic strategies based on CAR-engrafted $\mathrm{T}$ cells is the limited availability of appropriate surface TAAs. Finally, the short life-time of infused CAR-modified $\mathrm{T}$ cells results in limited antitumor responses. In vivo persistence might be prolonged by second or third generation CAR-engrafted $\mathrm{T}$ cells displaying increased proliferation rates and cytokine secretion, and which are more resistant to tumor-derived immunosuppressive factors. Currently several clinical studies are launched using second generation CARs and the field has to await, if this strategy can transfer the promise for tumor treatment from bench to bedside.

\section{References}

[1] S. A. Rosenberg, "Progress in human tumour immunology and immunotherapy," Nature, vol. 411, no. 6835, pp. 380384, 2001.

[2] R.-F. Wang, "The role of MHC class II-restricted tumor antigens and $\mathrm{CD}^{+} \mathrm{T}$ cells in antitumor immunity," Trends in Immunology, vol. 22, no. 5, pp. 269-276, 2001.

[3] S. A. Rosenberg, N. P. Restifo, J. C. Yang, R. A. Morgan, and M. E. Dudley, "Adoptive cell transfer: a clinical path to effective cancer immunotherapy," Nature Reviews Cancer, vol. 8, no. 4, pp. 299-308, 2008.

[4] K. S. Peggs, "Adoptive T cell immunotherapy for cytomegalovirus," Expert Opinion on Biological Therapy, vol. 9, no. 6, pp. 725-736, 2009.

[5] A. M. Leen, C. M. Rooney, and A. E. Foster, "Improving T cell therapy for cancer," Annual Review of Immunology, vol. 25, pp. 243-265, 2007.

[6] Y. Fujita, C. M. Rooney, and H. E. Heslop, "Adoptive cellular immunotherapy for viral diseases," Bone Marrow Transplantation, vol. 41, no. 2, pp. 193-198, 2008.

[7] S. A. Rosenberg and M. E. Dudley, "Adoptive cell therapy for the treatment of patients with metastatic melanoma," Current Opinion in Immunology, vol. 21, no. 2, pp. 233-240, 2009.

[8] G. M. Bendle, J. B. Haanen, and T. N. Schumacher, "Preclinical development of T cell receptor gene therapy," Current Opinion in Immunology, vol. 21, no. 2, pp. 209-214, 2009.

[9] W. Uckert and T. N. M. Schumacher, "TCR transgenes and transgene cassettes for TCR gene therapy: status in 2008," Cancer Immunology, Immunotherapy, vol. 58, no. 5, pp. 809822, 2009.

[10] M. Sadelain, I. Rivière, and R. Brentjens, "Targeting tumours with genetically enhanced T lymphocytes," Nature Reviews Cancer, vol. 3, no. 1, pp. 35-45, 2003.

[11] M. L. B. Becker, R. Near, M. Mudgett-Hunter, et al., "Expression of a hybrid immunoglobulin. T cell receptor protein in transgenic mice," Cell, vol. 58, no. 5, pp. 911-921, 1989.

[12] G. Gross, T. Waks, and Z. Eshhar, "Expression of immunoglobulin-T-cell receptor chimeric molecules as functional receptors with antibody-type specificity," Proceedings of the National Academy of Sciences of the United States of America, vol. 86, no. 24, pp. 10024-10028, 1989.

[13] Y. Kuwana, Y. Asakura, N. Utsunomiya, et al., "Expression of chimeric receptor composed of immunoglobulin-derived $\mathrm{V}$ regions and T-cell receptor-derived C regions," Biochemical and Biophysical Research Communications, vol. 149, no. 3, pp. 960-968, 1987.
[14] B. A. Irving, A. C. Chan, and A. Weiss, "Functional characterization of a signal transducing motif present in the T cell antigen receptor $\zeta$ chain," Journal of Experimental Medicine, vol. 177, no. 4, pp. 1093-1103, 1993.

[15] F. Letourneur and R. D. Klausner, "T-cell and basophil activation through the cytoplasmic tail of T-cell-receptor $\zeta$ family proteins," Proceedings of the National Academy of Sciences of the United States of America, vol. 88, no. 20, pp. 8905-8909, 1991.

[16] Z. Eshhar, T. Waks, G. Gross, and D. G. Schindler, "Specific activation and targeting of cytotoxic lymphocytes through chimeric single chains consisting of antibody-binding domains and the $\gamma$ or $\zeta$ subunits of the immunoglobulin and T-cell receptors," Proceedings of the National Academy of Sciences of the United States of America, vol. 90, no. 2, pp. 720 724, 1993.

[17] Z. Eshhar, N. Bach, C. J. Fitzer-Attas, et al., "The T-body approach: potential for cancer immunotherapy," Springer Seminars in Immunopathology, vol. 18, no. 2, pp. 199-209, 1996.

[18] C. H. June, "Adoptive T cell therapy for cancer in the clinic," Journal of Clinical Investigation, vol. 117, no. 6, pp. 14661476, 2007.

[19] B. Seliger, "Different regulation of MHC Class i antigen processing components in human tumors," Journal of Immunotoxicology, vol. 5, no. 4, pp. 361-367, 2008.

[20] M. R. Roberts, L. Qin, D. Zhang, et al., "Targeting of human immunodeficiency virus-infected cells by $\mathrm{CD}^{+} \mathrm{T}$ lymphocytes armed with universal T-cell receptors," Blood, vol. 84, no. 9, pp. 2878-2889, 1994.

[21] R. T. Mitsuyasu, P. A. Anton, S. G. Deeks, et al., "Prolonged survival and tissue trafficking following adoptive transfer of $\mathrm{CD} 4 \zeta$ gene-modified autologous $\mathrm{CD}^{+}$and $\mathrm{CD}^{+} \mathrm{T}$ cells in human immunodeficiency virus-infected subjects," Blood, vol. 96, no. 3, pp. 785-793, 2000.

[22] E. Elinav, T. Waks, and Z. Eshhar, "Redirection of regulatory $\mathrm{T}$ cells with predetermined specificity for the treatment of experimental colitis in mice," Gastroenterology, vol. 134, no. 7, pp. 2014-2024, 2008.

[23] E. Elinav, N. Adam, T. Waks, and Z. Eshhar, "Amelioration of colitis by genetically engineered murine regulatory $\mathrm{T}$ cells redirected by antigen-specific chimeric receptor," Gastroenterology, vol. 136, no. 5, pp. 1721-1731, 2009.

[24] A. A. Hombach, D. Kofler, G. Rappl, and H. Abken, "Redirecting human $\mathrm{CD} 4{ }^{+} \mathrm{CD} 25^{+}$regulatory T cells from the peripheral blood with pre-defined target specificity," Gene Therapy, vol. 16, no. 9, pp. 1088-1096, 2009.

[25] M. Sadelain, R. Brentjens, and I. Rivière, "The promise and potential pitfalls of chimeric antigen receptors," Current Opinion in Immunology, vol. 21, no. 2, pp. 215-223, 2009.

[26] S. Wilkie, G. Picco, J. Foster, et al., "Retargeting of human T cells to tumor-associated MUC1: the evolution of a chimeric antigen receptor," Journal of Immunology, vol. 180, no. 7, pp. 4901-4909, 2008.

[27] D. Mezzanzanica, S. Canevari, A. Mazzoni, et al., “Transfer of chimeric receptor gene made of variable regions of tumorspecific antibody confers anticarbohydrate specificity on $\mathrm{T}$ cells," Cancer Gene Therapy, vol. 5, no. 6, pp. 401-407, 1998.

[28] M. A. Pulè, K. C. Straathof, G. Dotti, H. E. Heslop, C. M. Rooney, and M. K. Brenner, "A chimeric T cell antigen receptor that augments cytokine release and supports clonal expansion of primary human T cells," Molecular Therapy, vol. 12, no. 5, pp. 933-941, 2005. 
[29] J. A. Westwood, M. J. Smyth, M. W. L. Teng, et al., "Adoptive transfer of $\mathrm{T}$ cells modified with a humanized chimeric receptor gene inhibits growth of Lewis-Y-expressing tumors in mice," Proceedings of the National Academy of Sciences of the United States of America, vol. 102, no. 52, pp. 19051-19056, 2005.

[30] T. M. J. Niederman, Z. Ghogawala, B. S. Carter, H. S. Tompkins, M. M. Russell, and R. C. Mulligan, "Antitumor activity of cytotoxic $\mathrm{T}$ lymphocytes engineered to target vascular endothelial growth factor receptors," Proceedings of the National Academy of Sciences of the United States of America, vol. 99, no. 10, pp. 7009-7014, 2002.

[31] C. R. J. Pameijer, A. Navanjo, B. Meechoovet, et al., "Conversion of a tumor-binding peptide identified by phage display to a functional chimeric T cell antigen receptor," Cancer Gene Therapy, vol. 14, no. 1, pp. 91-97, 2007.

[32] M. J. Stastny, C. E. Brown, C. Ruel, and M. C. Jensen, "Medulloblastomas expressing IL13R $\alpha 2$ are targets for IL13-zetakine + cytolytic T cells," Journal of Pediatric Hematology/Oncology, vol. 29, no. 10, pp. 669-677, 2007.

[33] K. S. Kahlon, C. Brown, L. J. N. Cooper, A. Raubitschek, S. J. Forman, and M. C. Jensen, "Specific recognition and killing of glioblastoma multiforme by interleukin 13-zetakine redirected cytolytic T cells," Cancer Research, vol. 64, no. 24, pp. 9160-9166, 2004.

[34] A. Muniappan, B. Banapour, J. Lebkowski, and S. Talib, "Ligand-mediated cytolysis of tumor cells: use of heregulin- $\zeta$ chimeras to redirect cytotoxic T lymphocytes," Cancer Gene Therapy, vol. 7, no. 1, pp. 128-134, 2000.

[35] T. Zhang, B. A. Lemoi, and C. L. Sentman, "Chimeric NKreceptor-bearing $\mathrm{T}$ cells mediate antitumor immunotherapy," Blood, vol. 106, no. 5, pp. 1544-1551, 2005.

[36] T. Zhang, A. Barber, and C. L. Sentman, "Chimeric NKG2Dmodified $\mathrm{T}$ cells inhibit systemic T-cell lymphoma growth in a manner involving multiple cytokines and cytotoxic pathways," Cancer Research, vol. 67, no. 22, pp. 11029-11036, 2007.

[37] A. Barber, T. Zhang, and C. L. Sentman, "Immunotherapy with chimeric NKG2D receptors leads to long-term tumorfree survival and development of host antitumor immunity in murine ovarian cancer," Journal of Immunology, vol. 180, no. 1, pp. 72-78, 2008.

[38] V. Groh, R. Rhinehart, H. Secrist, S. Bauer, K. H. Grabstein, and T. Spies, "Broad tumor-associated expression and recognition by tumor-derived $\gamma \delta$ T cells of MICA and MICB," Proceedings of the National Academy of Sciences of the United States of America, vol. 96, no. 12, pp. 6879-6884, 1999.

[39] C. MacCalli, S. Scaramuzza, and G. Parmiani, "TNK cells (NKG2D ${ }^{+} \mathrm{CD}^{+}$or $\mathrm{CD}^{+} \mathrm{T}$ lymphocytes) in the control of human tumors," Cancer Immunology, Immunotherapy, vol. 58, no. 5, pp. 801-808, 2009.

[40] G. Stewart-Jones, A. Wadle, A. Hombach, et al., "Rational development of high-affinity T-cell receptor-like antibodies," Proceedings of the National Academy of Sciences of the United States of America, vol. 106, no. 14, pp. 5784-5788, 2009.

[41] S. A. Richman and D. M. Kranz, "Display, engineering, and applications of antigen-specific T cell receptors," Biomolecular Engineering, vol. 24, no. 4, pp. 361-373, 2007.

[42] R. A. Beckman, L. M. Weiner, and H. M. Davis, "Antibody constructs in cancer therapy: protein engineering strategies to improve exposure in solid tumors," Cancer, vol. 109, no. 2, pp. 170-179, 2007.
[43] M. Chmielewski, A. Hombach, C. Heuser, G. P. Adams, and H. Abken, "T cell activation by antibody-like immunoreceptors: increase in affinity of the single-chain fragment domain above threshold does not increase $\mathrm{T}$ cell activation against antigen-positive target cells but decreases selectivity," Journal of Immunology, vol. 173, no. 12, pp. 7647-7653, 2004.

[44] F. Turatti, M. Figini, E. Balladore, et al., "Redirected activity of human antitumor chimeric immune receptors is governed by antigen and receptor expression levels and affinity of interaction," Journal of Immunotherapy, vol. 30, no. 7, pp. 684-693, 2007.

[45] A. A. Hombach, V. Schildgen, C. Heuser, R. Finnern, D. E. Gilham, and H. Abken, "T cell activation by antibody-like immunoreceptors: the position of the binding epitope within the target molecule determines the efficiency of activation of redirected T cells," Journal of Immunology, vol. 178, no. 7, pp. 4650-4657, 2007.

[46] L. Alvarez-Vallina and S. J. Russell, "Efficient discrimination between different densities of target antigen by tetracyclineregulatable T bodies," Human Gene Therapy, vol. 10, no. 4, pp. 559-563, 1999.

[47] M. E. M. Weijtens, E. H. Hart, and R. L. H. Bolhuis, "Functional balance between $\mathrm{T}$ cell chimeric receptor density and tumor associated antigen density: CTL mediated cytolysis and lymphokine production," Gene Therapy, vol. 7, no. 1, pp. 35-42, 2000.

[48] Z. Eshhar, "Tumor-specific T-bodies: towards clinical application,” Cancer Immunology Immunotherapy, vol. 45, no. 3-4, pp. 131-136, 1997.

[49] M. E. M. Weijtens, R. A. Willemsen, B. A. van Krimpen, and R. L. H. Bolhuis, "Chimeric scFv/ $\gamma$ receptor-mediated T-cell lysis of tumor cells is coregulated by adhesion and accessory molecules," International Journal of Cancer, vol. 77, no. 2, pp. 181-187, 1998.

[50] J. A. Westwood, W. K. Murray, M. Trivett, et al., "The Lewis$\mathrm{Y}$ carbohydrate antigen is expressed by many human tumors and can serve as a target for genetically redirected $\mathrm{T}$ cells despite the presence of soluble antigen in serum," Journal of Immunotherapy, vol. 32, no. 3, pp. 292-301, 2009.

[51] A. Hombach, D. Koch, R. Sircar, et al., "A chimeric receptor that selectively targets membrane-bound carcinoembryonic antigen (mCEA) in the presence of soluble CEA," Gene Therapy, vol. 6, no. 2, pp. 300-304, 1999.

[52] D. Moritz and B. Groner, "A spacer region between the single chain antibody-and the $\operatorname{CDS} \zeta$-chain domain of chimeric $\mathrm{T}$ cell receptor components is required for efficient ligand binding and signaling activity," Gene Therapy, vol. 2, no. 8, pp. 539-546, 1995.

[53] H. M. Finney, A. D. G. Lawson, C. R. Bebbington, and A. N. C. Weir, "Chimeric receptors providing both primary and costimulatory signaling in T cells from a single gene product," Journal of Immunology, vol. 161, no. 6, pp. 2791-2797, 1998.

[54] A. Hombach, R. Sircar, C. Heuser, et al., "Chimeric antiTAG72 receptors with immunoglobulin constant Fc domains and gamma or zeta signalling chains," International Journal of Molecular Medicine, vol. 2, no. 1, pp. 99-103, 1998.

[55] L. J. N. Cooper, M. S. Topp, L. M. Serrano, et al., "T-cell clones can be rendered specific for CD19: toward the selective augmentation of the graft-versus-B-lineage leukemia effect," Blood, vol. 101, no. 4, pp. 1637-1644, 2003.

[56] Z. Eshhar, T. Waks, A. Bendavid, and D. G. Schindler, "Functional expression of chimeric receptor genes in human T cells," Journal of Immunological Methods, vol. 248, no. 1-2, pp. 67-76, 2001. 
[57] P. K. Darcy, M. H. Kershaw, J. A. Trapani, and M. J. Smyth, "Expression in cytotoxic T lymphocytes of a singlechain anti-carcinoembryonic antigen antibody. Redirected Fas ligand-mediated lysis of colon carcinoma," European Journal of Immunology, vol. 28, no. 5, pp. 1663-1672, 1998.

[58] A. Morgenroth, M. Cartellieri, M. Schmitz, et al., "Targeting of tumor cells expressing the prostate stem cell antigen (PSCA) using genetically engineered T-cells," Prostate, vol. 67, no. 10, pp. 1121-1131, 2007.

[59] S. D. Patel, M. Moskalenko, D. Smith, B. Maske, M. H. Finer, and J. G. McArthur, "Impact of chimeric immune receptor extracellular protein domains on T cell function," Gene Therapy, vol. 6, no. 3, pp. 412-419, 1999.

[60] R. D. Guest, R. E. Hawkins, N. Kirillova, et al., "The role of extracellular spacer regions in the optimal design of chimeric immune receptors: evaluation of four different scFvs and antigens," Journal of Immunotherapy, vol. 28, no. 3, pp. 203211, 2005.

[61] S. E. James, P. D. Greenberg, M. C. Jensen, et al., "Antigen sensitivity of CD22-specific chimeric TCR is modulated by target epitope distance from the cell membrane," Journal of Immunology, vol. 180, no. 10, pp. 7028-7038, 2008.

[62] M. C. Gong, J.-B. Latouche, A. Krause, W. D. W. Heston, N. H. Bander, and M. Sadelain, "Cancer patient T cells genetically targeted to prostate-specific membrane antigen specifically lyse prostate cancer cells and release cytokines in response to prostate-specific membrane antigen," Neoplasia, vol. 1, no. 2, pp. 123-127, 1999.

[63] M. E. M. Weijtens, R. A. Willemsen, D. Valerio, K. Stam, and R. L. H. Bolhuis, "Single chain Ig/ $\gamma$ gene-redirected human T lymphocytes produce cytokines, specifically lyse tumor cells, and recycle lytic capacity," Journal of Immunology, vol. 157, no. 2, pp. 836-843, 1996.

[64] L. Ren-Heidenreich, R. Mordini, T. G. Hayman, R. Siebenlist, and A. LeFever, "Comparison of the TCR $\zeta$-chain with the FcR $\gamma$-chain in chimeric TCR constructs for T cell activation and apoptosis," Cancer Immunology, Immunotherapy, vol. 51, no. 8, pp. 417-423, 2002.

[65] N. M. Haynes, M. B. Snook, J. A. Trapani, et al., "Redirecting mouse CTL against colon carcinoma: superior signaling efficacy of single-chain variable domain chimeras containing TCR- $\zeta$ vs FceRI- $\gamma$," Journal of Immunology, vol. 166, no. 1 , pp. 182-187, 2001.

[66] C. Heuser, A. Hombach, C. Lösch, K. Manista, and H. Abken, "T-cell activation by recombinant immunoreceptors: impact of the intracellular signalling domain on the stability of receptor expression and antigen-specific activation of grafted T cells," Gene Therapy, vol. 10, no. 17, pp. 1408-1419, 2003.

[67] Y. Zhao, Q. J. Wang, S. Yang, et al., "A herceptin-based chimeric antigen receptor with modified signaling domains leads to enhanced survival of transduced T lymphocytes and antitumor activity," Journal of Immunology, vol. 183, no. 9, pp. 5563-5574, 2009.

[68] L. L. Parker, M. T. Do, J. A. Westwood, et al., "Expansion and characterization of $\mathrm{T}$ cells transduced with a chimeric receptor against ovarian cancer," Human Gene Therapy, vol. 11, no. 17, pp. 2377-2387, 2000.

[69] R. J. Brentjens, J.-B. Latouche, E. Santos, et al., "Eradication of systemic B-cell tumors by genetically targeted human T lymphocytes co-stimulated by CD80 and interleukin-15," Nature Medicine, vol. 9, no. 3, pp. 279-286, 2003.

[70] M. C. Jensen, L. J. N. Cooper, A. M. Wu, S. J. Forman, and A. Raubitschek, "Engineered CD20-specific primary human cytotoxic T lymphocytes for targeting B-cell malignancy," Cytotherapy, vol. 5, no. 2, pp. 131-138, 2003.

[71] L. J. N. Cooper, L. Ausubel, M. Gutierrez, et al., "Manufacturing of gene-modified cytotoxic T lymphocytes for autologous cellular therapy for lymphoma," Cytotherapy, vol. 8, no. 2, pp. 105-117, 2006.

[72] P. K. Darcy, N. M. Haynes, M. B. Snook, et al., "Redirected perforin-dependent lysis of colon carcinoma by ex vivo genetically engineered CTL," Journal of Immunology, vol. 164, no. 7, pp. 3705-3712, 2000.

[73] N. M. Haynes, J. A. Trapani, M. W. L. Teng, et al., "Rejection of syngeneic colon carcinoma by CTLs expressing singlechain antibody receptors codelivering CD28 costimulation," Journal of Immunology, vol. 169, no. 10, pp. 5780-5786, 2002.

[74] U. Altenschmidt, E. Klundt, and B. Groner, "Adoptive transfer of in vitro-targeted, activated T lymphocytes results in total tumor regression," Journal of Immunology, vol. 159, no. 11, pp. 5509-5515, 1997.

[75] P. Hwu, J. C. Yang, R. Cowherd, et al., "In vivo antitumor activity of $\mathrm{T}$ cells redirected with chimeric antibody/T-cell receptor genes," Cancer Research, vol. 55, no. 15, pp. 33693373, 1995.

[76] G. Wang, R. K. Chopra, R. E. Royal, J. C. Yang, S. A. Rosenberg, and P. Hwu, "A T cell-independent antitumor response in mice with bone marrow cells retrovirally transduced with an antibody/Fc- $\gamma$ chain chimetic receptor gene recognizing a human ovarian cancer antigen," Nature Medicine, vol. 4, no. 2, pp. 168-172, 1998.

[77] J. H. Pinthus, T. Waks, K. Kaufman-Francis, et al., "Immunogene therapy of established prostate tumors using chimeric receptor-redirected human lymphocytes," Cancer Research, vol. 63, no. 10, pp. 2470-2476, 2003.

[78] J. H. Pinthus, T. Waks, V. Malina, et al., "Adoptive immunotherapy of prostate cancer bone lesions using redirected effector lymphocytes," Journal of Clinical Investigation, vol. 114, no. 12, pp. 1774-1781, 2004.

[79] Q. Ma, M. Safar, E. Holmes, Y. Wang, A. L. Boynton, and R. P. Junghans, "Anti-prostate specific membrane antigen designer T cells for prostate cancer therapy," Prostate, vol. 61, no. 1, pp. 12-25, 2004.

[80] N. Ahmed, M. Ratnayake, B. Savoldo, et al., "Regression of experimental medulloblastoma following transfer of HER2specific T cells," Cancer Research, vol. 67, no. 12, pp. 59575964, 2007.

[81] T. Brocker and K. Karjalainen, "Adoptive tumor immunity mediated by lymphocytes bearing modified antigen-specific receptors," Advances in Immunology, vol. 68, pp. 257-269, 1998.

[82] T. Brocker, "Chimeric Fv- $\zeta$ or Fv- $\varepsilon$ receptors are not sufficient to induce activation or cytokine production in peripheral $\mathrm{T}$ cells," Blood, vol. 96, no. 5, pp. 1999-2001, 2000.

[83] S. W. Van Gool, P. Vandenberghe, M. de Boer, and J. L. Ceuppens, "CD80, CD86 and CD40 provide accessory signals in a multiple-step T-Cell activation model," Immunological Reviews, no. 153, pp. 47-83, 1996.

[84] T. P. F. Gade, W. Hassen, E. Santos, et al., "Targeted elimination of prostate cancer by genetically directed human T lymphocytes," Cancer Research, vol. 65, no. 19, pp. 90809088, 2005.

[85] L. Alvarez-Vallina and R. E. Hawkins, "Antigen-specific targeting of CD28-mediated $\mathrm{T}$ cell co-stimulation using chimeric single-chain antibody variable fragment-CD28 receptors," European Journal of Immunology, vol. 26, no. 10, pp. 2304-2309, 1996. 
[86] A. Krause, H.-F. Guo, J.-B. Latouche, C. Tan, N.-K.V. Cheung, and M. Sadelain, "Antigen-dependent CD28 signaling selectively enhances survival and proliferation in genetically modified activated human primary T lymphocytes," Journal of Experimental Medicine, vol. 188, no. 4, pp. 619-626, 1998.

[87] T. L. Geiger, P. Nguyen, D. Leitenberg, and R. A. Flavell, "Integrated src kinase and costimulatory activity enhances signal transduction through single-chain chimeric receptors in T lymphocytes," Blood, vol. 98, no. 8, pp. 2364-2371, 2001.

[88] E. J. Beecham, Q. Ma, R. Ripley, and R. P. Junghans, "Coupling CD28 Co-stimulation to immunoglobulin T-cell receptor molecules: the dynamics of t-cell proliferation and death," Journal of Immunotherapy, vol. 23, no. 6, pp. 631-642, 2000.

[89] J. Maher, R. J. Brentjens, G. Gunset, I. Rivière, and M. Sadelain, "Human T-lymphocyte cytotoxicity and proliferation directed by a single chimeric TCR $\zeta / C D 28$ receptor," Nature Biotechnology, vol. 20, no. 1, pp. 70-75, 2002.

[90] A. Hombach, D. Sent, C. Schneider, et al., "T-cell activation by recombinant receptors: $\mathrm{CD} 28$ costimulation is required for interleukin 2 secretion and receptor-mediated T-cell proliferation but does not affect receptor-mediated target cell lysis," Cancer Research, vol. 61, no. 5, pp. 1976-1982, 2001.

[91] A. Hombach, A. Wieczarkowiecz, T. Marquardt, et al., "Tumor-specific $\mathrm{T}$ cell activation by recombinant immunoreceptors: $\mathrm{CD} 3 \zeta$ signaling and CD28 costimulation are simultaneously required for efficient IL-2 secretion and can be integrated into one combined $\mathrm{CD} 28 / \mathrm{CD} 3 \zeta$ signaling receptor molecule," Journal of Immunology, vol. 167, no. 11, pp. 6123-6131, 2001.

[92] H. M. Finney, A. N. Akbar, and A. D. G. Lawson, "Activation of resting human primary $\mathrm{T}$ cells with chimeric receptors: costimulation from CD28, inducible costimulator, CD134, and CD137 in series with signals from the TCR $\zeta$ chain," Journal of Immunology, vol. 172, no. 1, pp. 104-113, 2004.

[93] C. M. Kowolik, M. S. Topp, S. Gonzalez, et al., "CD28 costimulation provided through a CD19-specific chimeric antigen receptor enhances in vivo persistence and antitumor efficacy of adoptively transferred T cells," Cancer Research, vol. 66, no. 22, pp. 10995-11004, 2006.

[94] N. M. Haynes, J. A. Trapani, M. W. L. Teng, et al., "Singlechain antigen recognition receptors that costimulate potent rejection of established experimental tumors," Blood, vol. 100, no. 9, pp. 3155-3163, 2002.

[95] J. Vera, B. Savoldo, S. Vigouroux, et al., “T lymphocytes redirected against the $\kappa$ light chain of human immunoglobulin efficiently kill mature B lymphocyte-derived malignant cells," Blood, vol. 108, no. 12, pp. 3890-3897, 2006.

[96] R. J. Brentjens, E. Santos, Y. Nikhamin, et al., "Genetically targeted $\mathrm{T}$ cells eradicate systemic acute lymphoblastic leukemia xenografts," Clinical Cancer Research, vol. 13, no. 18, pp. 5426-5435, 2007.

[97] D. Friedmann-Morvinski, A. Bendavid, T. Waks, D. Schindler, and Z. Eshhar, "Redirected primary T cells harboring a chimeric receptor require costimulation for their antigen-specific activation," Blood, vol. 105, no. 8, pp. 3087-3093, 2005.

[98] G. A. Rabinovich, D. Gabrilovich, and E. M. Sotomayor, "Immunosuppressive strategies that are mediated by tumor cells," Annual Review of Immunology, vol. 25, pp. 267-296, 2007.

[99] H. Koehler, D. Kofler, A. Hombach, and H. Abken, "CD28 costimulation overcomes transforming growth factor- $\beta$ mediated repression of proliferation of redirected human
$\mathrm{CD}^{+}$and $\mathrm{CD} 8^{+} \mathrm{T}$ cells in an antitumor cell attack," Cancer Research, vol. 67, no. 5, pp. 2265-2273, 2007.

[100] A. Loskog, V. Giandomenico, C. Rossig, M. Pule, G. Dotti, and M. K. Brenner, "Addition of the CD28 signaling domain to chimeric T-cell receptors enhances chimeric T-cell resistance to T regulatory cells," Leukemia, vol. 20, no. 10, pp. 1819-1828, 2006.

[101] W. Zou, "Regulatory $\mathrm{T}$ cells, tumour immunity and immunotherapy," Nature Reviews Immunology, vol. 6, no. 4, pp. 295-307, 2006.

[102] M. Croft, "The role of TNF superfamily members in T-cell function and diseases," Nature Reviews Immunology, vol. 9, no. 4, pp. 271-285, 2009.

[103] R. J. Greenwald, G. J. Freeman, and A. H. Sharpe, “The B7 family revisited," Annual Review of Immunology, vol. 23, pp. 515-548, 2005.

[104] A. Hombach and H. Abken, "Costimulation tunes tumorspecific activation of redirected $\mathrm{T}$ cells in adoptive immunotherapy," Cancer Immunology, Immunotherapy, vol. 56, no. 5, pp. 731-737, 2007.

[105] J. E. Smith-Garvin, G. A. Koretzky, and M. S. Jordan, “T cell activation," Annual Review of Immunology, vol. 27, pp. 591619, 2009.

[106] W. L. Redmond, C. E. Ruby, and A. D. Weinberg, "The role of OX40-mediated co-stimulation in T-cell activation and survival," Critical Reviews in Immunology, vol. 29, no. 3, pp. 187-201, 2009.

[107] I. Melero, O. Murillo, J. Dubrot, S. Hervás-Stubbs, and J. L. Perez-Gracia, "Multi-layered action mechanisms of CD137 (4-1BB)-targeted immunotherapies," Trends in Pharmacological Sciences, vol. 29, no. 8, pp. 383-390, 2008.

[108] M. T. Stephan, V. Ponomarev, R. J. Brentjens, et al., “T cellencoded CD80 and 4-1BBL induce auto- and transcostimulation, resulting in potent tumor rejection," Nature Medicine, vol. 13, no. 12, pp. 1440-1449, 2007.

[109] H. Zhang, K. M. Snyder, M. M. Suhoski, et al., "4-1BB is superior to CD28 costimulation for generating $\mathrm{CD}^{+}$ cytotoxic lymphocytes for adoptive immunotherapy," Journal of Immunology, vol. 179, no. 7, pp. 4910-4918, 2007.

[110] M. C. Milone, J. D. Fish, C. Carpenito, et al., "Chimeric receptors containing CD137 signal transduction domains mediate enhanced survival of $\mathrm{T}$ cells and increased antileukemic efficacy in vivo," Molecular Therapy, vol. 17, no. 8, pp. 1453-1464, 2009.

[111] J. Wang, M. Jensen, Y. Lin, et al., "Optimizing adoptive polyclonal $\mathrm{T}$ cell immunotherapy of lymphomas, using a chimeric $\mathrm{T}$ cell receptor possessing CD28 and CD137 costimulatory domains," Human Gene Therapy, vol. 18, no. 8, pp. 712-725, 2007.

[112] C. Carpenito, M. C. Milone, R. Hassan, et al., "Control of large, established tumor xenografts with genetically retargeted human T cells containing CD28 and CD137 domains," Proceedings of the National Academy of Sciences of the United States of America, vol. 106, no. 9, pp. 3360-3365, 2009.

[113] C. H. June, "Principles of adoptive T cell cancer therapy," Journal of Clinical Investigation, vol. 117, no. 5, pp. 12041212, 2007.

[114] P. Muranski and N. P. Restifo, "Adoptive immunotherapy of cancer using CD $4^{+} \mathrm{T}$ cells," Current Opinion in Immunology, vol. 21, no. 2, pp. 200-208, 2009.

[115] A. Hombach, C. Heuser, T. Marquardt, et al., "CD4+ T cells engrafted with a recombinant immunoreceptor efficiently 
lyse target cells in a MHC antigen- and Fas-independent fashion," Journal of Immunology, vol. 167, no. 2, pp. 10901096, 2001.

[116] A. Hombach, H. Köhler, G. Rappl, and H. Abken, "Human $\mathrm{CD}^{+} \mathrm{T}$ cells lyse target cells via granzyme/perforin upon circumvention of MHC class II restriction by an antibodylike immunoreceptor," Journal of Immunology, vol. 177, no. 8, pp. 5668-5675, 2006.

[117] S. Landmeier, B. Altvater, S. Pscherer, et al., "Geneengineered varicella-zoster virus-reactive $\mathrm{CD}^{+}$cytotoxic $\mathrm{T}$ cells exert tumor-specific effector function," Cancer Research, vol. 67, no. 17, pp. 8335-8343, 2007.

[118] M. Moeller, N. M. Haynes, M. H. Kershaw, et al., "Adoptive transfer of gene-engineered $\mathrm{CD}^{+}$helper $\mathrm{T}$ cells induces potent primary and secondary tumor rejection," Blood, vol. 106, no. 9, pp. 2995-3003, 2005.

[119] D. Kabelitz, D. Wesch, and W. He, "Perspectives of $\gamma \delta$ T cells in tumor immunology," Cancer Research, vol. 67, no. 1, pp. 5-8, 2007.

[120] M. Rischer, S. Pscherer, S. Duwe, J. Vormoor, H. Jürgens, and C. Rossig, "Human $\gamma \delta$ T cells as mediators of chimaericreceptor redirected anti-tumour immunity," British Journal of Haematology, vol. 126, no. 4, pp. 583-592, 2004.

[121] F. Sallusto, D. Lenig, R. Förster, M. Lipp, and A. Lanzavecchia, "Two subsets of memory $\mathrm{T}$ lymphocytes with distinct homing potentials and effector functions," Nature, vol. 401, no. 6754, pp. 708-712, 1999.

[122] L. Lefrançois and A. L. Marzo, "Opinion: the descent of memory T-cell subsets," Nature Reviews Immunology, vol. 6, no. 8, pp. 618-623, 2006.

[123] L. Gattinoni, C. A. Klebanoff, D. C. Palmer, et al., "Acquisition of full effector function in vitro paradoxically impairs the in vivo antitumor efficacy of adoptively transferred CD8 ${ }^{+}$ T cells," Journal of Clinical Investigation, vol. 115, no. 6, pp. 1616-1626, 2005.

[124] C. A. Klebanoff, L. Gattinoni, P. Torabi-Parizi, et al., "Central memory self/tumor-reactive $\mathrm{CD}^{+} \mathrm{T}$ cells confer superior antitumor immunity compared with effector memory $\mathrm{T}$ cells," Proceedings of the National Academy of Sciences of the United States of America, vol. 102, no. 27, pp. 9571-9576, 2005.

[125] C. Berger, M. C. Jensen, P. M. Lansdorp, M. Gough, C. Elliott, and S. R. Riddell, "Adoptive transfer of effector CD8 ${ }^{+} \mathrm{T}$ cells derived from central memory cells establishes persistent $\mathrm{T}$ cell memory in primates," Journal of Clinical Investigation, vol. 118, no. 1, pp. 294-305, 2008.

[126] P. Shrikant and M. F. Mescher, "Opposing effects of IL-2 in tumor immunotherapy: promoting CD8 T cell growth and inducing apoptosis," Journal of Immunology, vol. 169, no. 4, pp. 1753-1759, 2002.

[127] E. M. van Leeuwen, J. Sprent, and C. D. Surh, "Generation and maintenance of memory $\mathrm{CD} 4^{+} \mathrm{T}$ cells," Current Opinion in Immunology, vol. 21, no. 2, pp. 167-172, 2009.

[128] C. D. Surh and J. Sprent, "Homeostasis of naive and memory T cells," Immunity, vol. 29, no. 6, pp. 848-862, 2008.

[129] O. Boyman, S. Létourneau, C. Krieg, and J. Sprent, "Homeostatic proliferation and survival of naïve and memory T cells," European Journal of Immunology, vol. 39, no. 8, pp. 20882094, 2009.

[130] C. Quintarelli, J. F. Vera, B. Savoldo, et al., "Co-expression of cytokine and suicide genes to enhance the activity and safety of tumor-specific cytotoxic T lymphocytes," Blood, vol. 110, no. 8, pp. 2793-2802, 2007.
[131] J. F. Vera, V. Hoyos, B. Savoldo, et al., "Genetic manipulation of tumor-specific cytotoxic T lymphocytes to restore responsiveness to IL-7," Molecular Therapy, vol. 17, no. 5, pp. 880888, 2009.

[132] S. Landmeier, B. Altvater, S. Pscherer, et al., "Activated human $\gamma \delta \mathrm{T}$ cells as stimulators of specific $\mathrm{CD}^{+} \mathrm{T}$-cell responses to subdominant epstein barr virus epitopes: potential for immunotherapy of cancer," Journal of Immunotherapy, vol. 32, no. 3, pp. 310-321, 2009.

[133] C. Rossig, C. M. Bollard, J. G. Nuchtern, C. M. Rooney, and M. K. Brenner, "Epstein-Barr virus-specific human T lymphocytes expressing antitumor chimeric T-cell receptors: potential for improved immunotherapy," Blood, vol. 99, no. 6, pp. 2009-2016, 2002.

[134] C. Rossig, A. Bär, S. Pscherer, et al., "Target antigen expression on a professional antigen-presenting cell induces superior proliferative antitumor T-cell responses via chimeric Tcell receptors," Journal of Immunotherapy, vol. 29, no. 1, pp. 21-31, 2006.

[135] B. Savoldo, C. M. Rooney, A. Di Stasi, et al., "Epstein Barr virus-specific cytotoxic T lymphocytes expressing the antiCD30 $\zeta$ artificial chimeric T-cell receptor for immunotherapy of Hodgkin disease," Blood, vol. 110, no. 7, pp. 2620-2630, 2007.

[136] A. Di Stasi, B. De Angelis, C. M. Rooney, et al., "T lymphocytes coexpressing CCR4 and a chimeric antigen receptor targeting CD30 have improved homing and antitumor activity in a Hodgkin tumor model," Blood, vol. 113, no. 25, pp. 6392-6402, 2009.

[137] D. Sauce, N. Tonnelier, A. Duperrier, et al., "Influence of ex vivo expansion and retrovirus-mediated gene transfer on primary T lymphocyte phenotype and functions," Journal of Hematotherapy and Stem Cell Research, vol. 11, no. 6, pp. 929-940, 2002

[138] C. S. Hinrichs, Z. A. Borman, L. Cassard, et al., "Adoptively transferred effector cells derived from naïve rather than central memory $\mathrm{CD}^{+} \mathrm{T}$ cells mediate superior antitumor immunity," Proceedings of the National Academy of Sciences of the United States of America, vol. 106, no. 41, pp. 1746917474, 2009.

[139] S. Cavalieri, S. Cazzaniga, M. Geuna, et al., "Human T lymphocytes transduced by lentiviral vectors in the absence of TCR activation maintain an intact immune competence," Blood, vol. 102, no. 2, pp. 497-505, 2003.

[140] L. M. Serrano, T. Pfeiffer, S. Olivares, et al., "Differentiation of naive cord-blood T cells into CD19-specific cytolytic effectors for posttransplantation adoptive immunotherapy," Blood, vol. 107, no. 7, pp. 2643-2652, 2006.

[141] K. Birkholz, A. Hombach, C. Krug, et al., "Transfer of mRNA encoding recombinant immunoreceptors reprograms $\mathrm{CD}^{+}$ and $\mathrm{CD} 8^{+} \mathrm{T}$ cells for use in the adoptive immunotherapy of cancer," Gene Therapy, vol. 16, no. 5, pp. 596-604, 2009.

[142] H. Singh, P. R. Manuri, S. Olivares, et al., "Redirecting specificity of T-cell populations for CD19 using the sleeping beauty system," Cancer Research, vol. 68, no. 8, pp. 29612971, 2008.

[143] P. V. Raja Manuri, M. H. Wilson, S. N. Maiti, et al., "piggyBac transposon/transposase system to generate CD19-specific T cells for treatment of B-lineage malignancies," Human Gene Therapy, vol. 21, no. 4, pp. 427-437, 2010.

[144] X. Huang, H. Guo, J. Kang, et al., "Sleeping beauty transposon-mediated engineering of human primary $\mathrm{T}$ cells for therapy of $\mathrm{CD} 19^{+}$lymphoid malignancies," Molecular Therapy, vol. 16, no. 3, pp. 580-589, 2008. 
[145] C. H. Lamers, S. Sleijfer, A. G. Vulto, et al., "Treatment of metastatic renal cell carcinoma with autologous Tlymphocytes genetically retargeted against carbonic anhydrase IX: first clinical experience," Journal of Clinical Oncology, vol. 24, no. 13, pp. e20-e22, 2006.

[146] C. H. J. Lamers, S. C. L. Langeveld, C.M. Groot-van Ruijven, R. Debets, S. Sleijfer, and J. W. Gratama, "Gene-modified $\mathrm{T}$ cells for adoptive immunotherapy of renal cell cancer maintain transgene-specific immune functions in vivo," Cancer Immunology, Immunotherapy, vol. 56, no. 12, pp. 1875-1883, 2007.

[147] M. H. Kershaw, J. A. Westwood, L. L. Parker, et al., "A phase I study on adoptive immunotherapy using gene-modified T cells for ovarian cancer," Clinical Cancer Research, vol. 12, no. 20, pp. 6106-6115, 2006.

[148] J. R. Park, D. L. DiGiusto, M. Slovak, et al., "Adoptive transfer of chimeric antigen receptor re-directed cytolytic T lymphocyte clones in patients with neuroblastoma," Molecular Therapy, vol. 15, no. 4, pp. 825-833, 2007.

[149] B. G. Till, M. C. Jensen, J. Wang, et al., "Adoptive immunotherapy for indolent non-hodgkin lymphoma and mantle cell lymphoma using genetically modified autologous CD20-specific T cells," Blood, vol. 112, no. 6, pp. 2261-2271, 2008.

[150] M. A. Pule, B. Savoldo, G. D. Myers, et al., "Virus-specific $T$ cells engineered to coexpress tumor-specific receptors: persistence and antitumor activity in individuals with neuroblastoma," Nature Medicine, vol. 14, no. 11, pp. 1264-1270, 2008. 


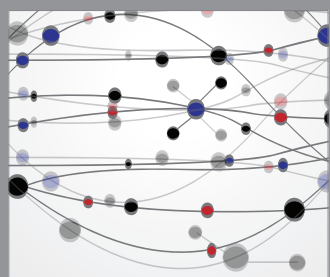

The Scientific World Journal
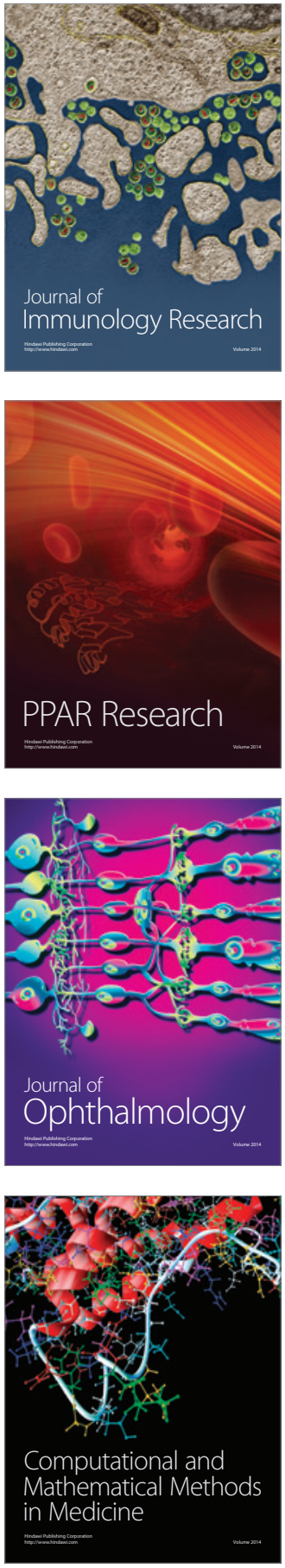

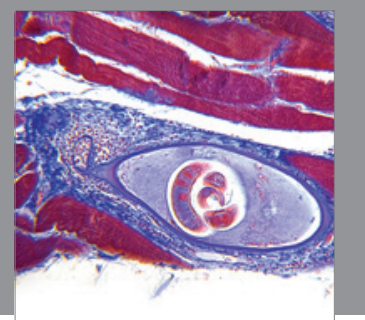

Gastroenterology

Research and Practice
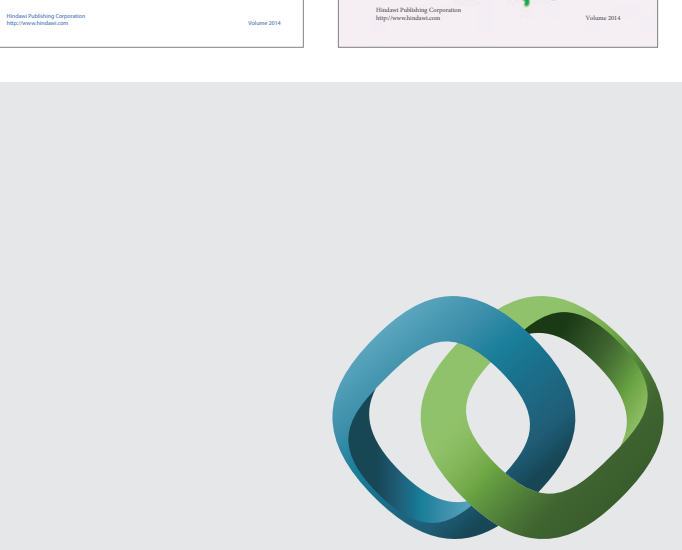

\section{Hindawi}

Submit your manuscripts at

http://www.hindawi.com
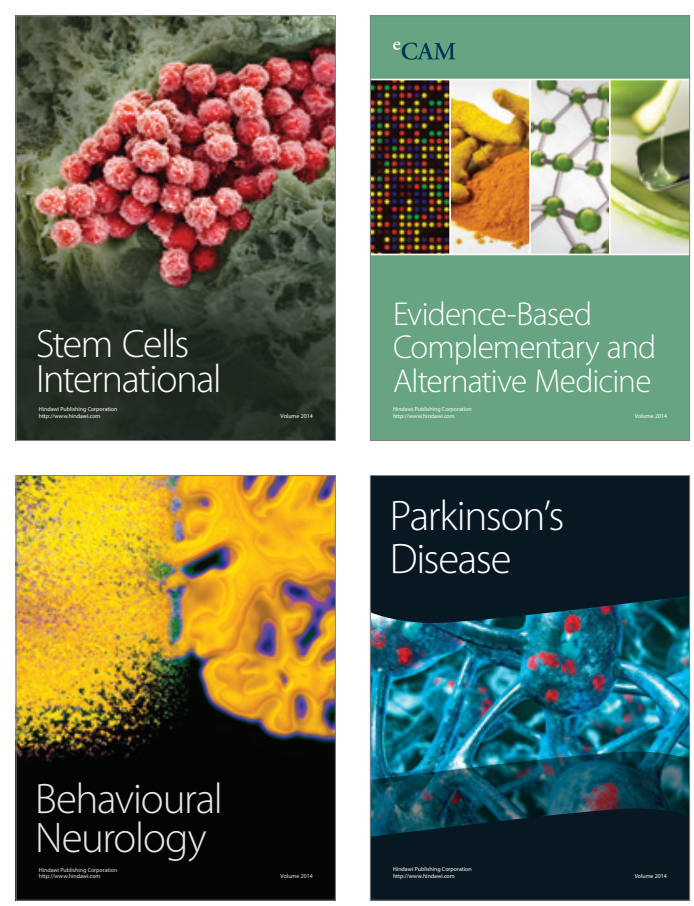

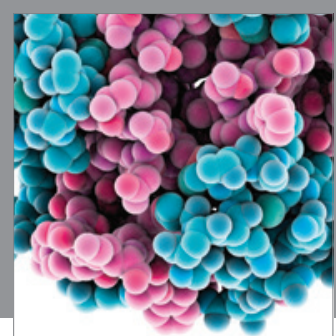

Journal of
Diabetes Research

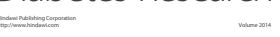

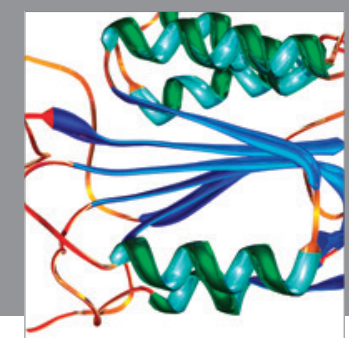

Disease Markers
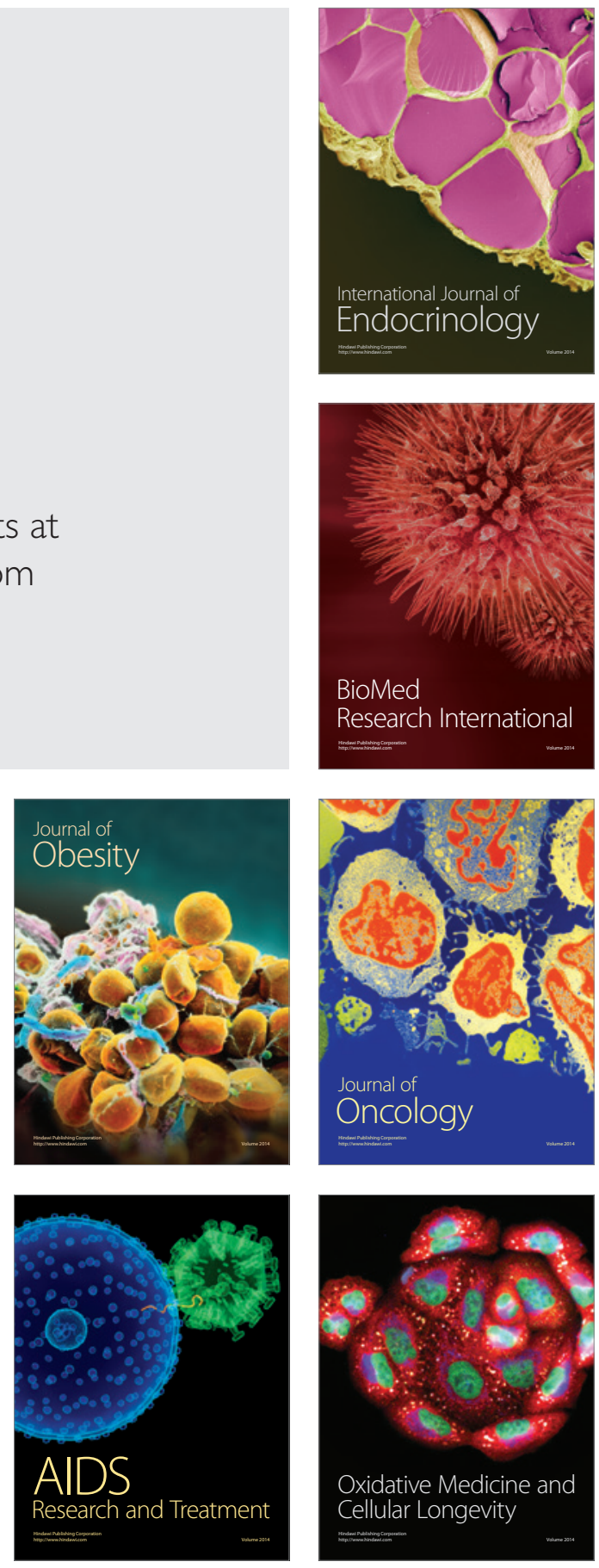